\title{
EKLEZJALNY ASPEKT POWOŁANIA W WYPOWIEDZIACH II SOBORU WATYKAŃSKIEGO
}

Biblijna idea powołania znalazła w dokumentach II Soboru Watykańskiego poczesne miejsce. Swiadczy o tym częste pojawianie się w nich terminu: „powołanie” i wyrażeń pokrewnych. Używa się ich na wielu miejscach w konstytucjach: dogmatycznej i pastoralnej o Kościele, o świętej liturgii; w dekretach: o apostolstwie świeckich, o działalności misyjnej Kościoła, o posłudze i życiu kapłańskim, o pasterskich zadaniach biskupów w Kościele, o formacji kapłańskiej, o przystosowanej odnowie życia zakonnego; w deklaracjach: o wychowaniu chrześcijańskim i o stosunku Kościoła do religii niechrześcijańskich. W konstytucjach o Kościele i w dekretach: o apostolstwie świeckich, o posłudze i życiu kapłańskim i o formacji kapłańskiej, znajdujemy to wyrażenie na określenie części, rozdziałów i podrozdziałów ${ }^{1}$. Prawda o powołaniu jest dla Soboru ideą kluczową i stanowi dlań punkt wyjścia w ujmowaniu wielu zagadnień z dziedziny wiary i obyczajów. Co więcej, dekret o formacji kapłańskiej postuluje, aby naukowy wykład teologii moralnej ukazywał w większej mierze niż dotąd wzniosłość powołania wiernych w Chrystusie (por. DFK 16).

Idea powołania została więc na nowo przypomniana dzisiejszym czasom. Rzeczywiście, nie trudno zauważyć, że w historii dokumentów Koś-

1 Część I konstytucji duszpasterskiej o Kościele nosi tytuł: „Kościół i powołanie człowieka" (De Ecclesia et vocatione hominis); rozdział V konstytucji dogmatycznej - Kościele - „Powszechne powołanie do świętości w Kościele” (De universali vocatione ad sanctitatem in Ecclesia); rozdział I dekretu o apostolstwie świesk:ch „Powołanie świeckich do apostolstwa" (De vocatione laicorum ad apostolatum); dekret o formacji kapłanów II-giemu rozdziałowi daje tytuł: „Intensywniejsze budzenie powołań kapłańskich" (De vocationibus sacerdotalibus "instantius fovendis); III podrozdział rozdziału I dekretu o życiu i posłudze kapłanów zatytułowany jest: „Rozmieszczenie prezbiterów i powołania kapłańskie" (Presbyterorum distributio et vocationes sacerdotales), a I podrozdzial rozdziału III — „Powołanie prezbiterów do doskonałości" (Presbyterorum ad perfectionem vocatio). 
cioła Nauczającego nigdy nie była ona stosowana w takim stopniu i w takim wymiarze. Papieże naszego stulecia zabierają wprawdzie głos na temat powołania, stosują jednak ten termin w odniesieniu do wezwania Bożego skierowanego do kapłanów i osób zakonnych ${ }^{2}$. Nie mówią oni wprost o powołaniu ogólnoludzkim i ogólnochrześcijańskim. Wyjątek stanowi przemówienie Piusa XII z wigilii Bożego Narodzenia 1957 r., gdzie papież poświęcił kilka zdań powołaniu do życia chrześcijańskiego i związanej z tym odpowiedzialności ${ }^{3}$. Trzeba jednak stwierdzić, że Pius XII przez swe encykliki i liczne przemówienia do różnych stanów, zawodów i grup doskonale przygotował grunt pod soborową myśl o powołaniu 4 . To samo należy powiedzieć o niektórych encyklikach i przemówieniach Jana XXIII ${ }^{5}$.

Jest rzeczą charakterystyczną, że idea powołania została przypomniana światu z taką wyrazistością w ścisłym związku z prawdą o Kościele. Nie jest dziełem przypadku, że najwięcej myśli na ten temat znajdujemy w obydwóch konstytucjach o Kościele. Wymowną w tej materii jest również historia powstawania konstytucji dogmatycznej o Kościele. Pierwszy jej projekt został odrzucony jako zbyt jurydyczny i tryumfalistyczny. Projekt drugi został przyjęty przez ojców Soboru jako podstawa do dalszych dyskusji. Zawierał on wiele treści biblijnych, a prawdę o Kościele ukazywał w najściślejszym powiązaniu z ideą powołania Ludu Bożego do świętości. Dalsze projekty jeszcze bardziej uwydatniały rolę Ludu Bożego w Kościele, a tym samym coraz mocniej podkreślały powołanie wynikające $\mathrm{z}$ chrztu świętego. Powołania partykularne, a więc powołanie laikatu, kapłańskie, zakonne, zawodowe, zostały przedstawione w ścisłym związku z powołaniem ogólnochrześcijańskim. Wszystkie rodzaje powołań zostały doskonale wkomponowane w wykład doktryny o Kościele ${ }^{6}$.

Ten organiczny związek idei powołania z tajemnicą Kościoła domaga się bardziej wnikliwej refleksji. Aby go ukazać, aby wskazać na eklezjalny wymiar powołania w wypowiedziach II Soboru Watykańskiego, niniejszy artykuł zamierza przedłożyć, że według tegoż Soboru Kościół jest rezultatem powołania człowieka ze strony Boga; że jako rzeczywistość wiary ma on sobie właściwe powołanie; że jest miejscem urzeczy-

2 Por. Adhortacja św. Piusa X „Haerent animo”, ASS 41 (1908) 576; encyklika Benedykta XV „Humani generis”, AAS 9 (1917) 308 n.; enc. Piusa XI „Ad sacerdotii nostri fastigium”, AAS 28 (1936) 46-49; adh. Piusa XII ,Menti Nostrae”, AAS 42 (1950) 682-685; allokucja Piusa XII „Annus sacer”, AAS 43 (1951) 31.

3 AAS 50 (1958) 5-24.

4 Pius XII w czasie swego pontyfikatu napisał kilka encyklik i adhortacji i wygłosił wiele przemówien do rozmaitych grup stanowych i zawodowych dając w ten sposób podwaliny pod teologię duchowości poszczególnych stanów i zawodów.

5 Np. enc. „Princeps Pastorum”, AAS 51 (1969) 833-864.

- Por. Ks. Jerzy Bajda „Biblijna koncepcja powolania chrześcijańskiego w genezie konstytucji dogmatycznej o Kościele”, „Analecta Cracoviensia”, 2 (1970) 234. 
wistniania się powołań poszczególnych swych członków; że jest celem tychże powołań i wreszcie, że sam Kościół jest powołującym.

\section{KOSCIÓE REZULTATEM POWOEAÑ LUDZI DO ZBAWIENIA}

Kościół jest wspólnotą ludzi powołanych przez Boga w Jezusie Chrystusie. Jest zwolaniem ludzi w jedną rodzinę ${ }^{7}$; ,jest $w$ Chrystusie niejako sakramentem, czyli znakiem i narzędziem wewnętrznego zjednoczeria z Bogiem i jedności całego rodzaju ludzkiego" (KK 1). Na samym początku konstytucja dogmatyczna o Kościele uczy: „Przedwieczny Ojciec, na skutek najzupełniej wolnego i tajemnego zamysłu swej mądrości i dobrcci, stworzył cały świat, a ludzi postanowił wynieść do uczestrictwa w życiu Bożym; nie opuścił ich też po ich upadku w Adamie, dając im nieustannie pomoce do zbawienia, przez wzgląd na Chrystusa, Odkupiciela" (KK 2). To ujęcie tajemnicy Kościoła jest wyraźnym nawiązaniem do klasycznego tekstu listu św. Pawła do Rzymian $(8,29)$. Apostoł Narodów umieszcza tam powołanie wśród czterech słów, określających doskonale zbawczy plan Boga wobec człowieka: „Albowiem tych, których od wieków poznał, tych też przeznaczył na to, by się stali na wzór obrazu Jego Syna, aby On był pierworodnym między wielu braćmi. Tych zaś, których przeznaczył, tych tė powołał, a których powołał tych tez usprawiedliwił, a których usprawiedliwił tych też obdarzył chwałą". Plan Boży wobec ludzi urzeczywistnia się poprzez Kościół i dlatego po nawiązaniu do listu św. Pawła Sobór dorzuca: „, a wierzących w Chrystusa postanowił zgromadzić w Kościele” (KK 2). Jest więc Kościół dla Soboru realizacją planów Boga wobec czlowieka, wynikiem powołania ludzi do zbawienia.

Dokumenty soborowe nie ograniczają jednak prawdy o zwołaniu Kościoła do jednorazowego faktu jego zaistnienia w historii ludzkiej, ale ukazują ją jako rzeczywistość wciąż aktualizującą się: „Kościół, czyli Królestwo Chrystusowe, już teraz obecne w tajemnicy, dzięki mocy Bożej rośnie w sposób widzialny w świecie" (KK 3). Pełne zwołanie Kościoła nastąpi depiero na końcu dziejów. „Wtedy... wszyscy sprawiedliwi, poczynając od Adama, 'od Abla sprawiedliwego aż po ostatniego wybranego', zostaną zgromadzeni w Kościele powszechnym u Ojca" (KK 2).

7 Autorzy natchnieni Nowego Testamentu mówiąc o powołaniu posługują się najczęściej czasownikami: ,kaléo" i ,eklégomai” znaczy „wołać”, „wzywać", ,nazywać”, ,zapraszać". Stąd: ,klēsis" = ,powołanie” lub ,klétós" = ,powołany". Niekiedy zamiast zwykłego "kaléo" występuje złożenie ,ek-kaléo". Z tego powodu społeczność ludzi, których zwołanie razem jest przedstawione za pomocą tego słowa, określa się terminem „ekklesia”. Por. Ks. Kazimierz Romaniuk, Powolanie w Biblii, Katowice 1975, 9. 
Sobór dostrzega podwójny wymiar zwoływania Kościoła: zewnętrzny i wewnętrzny. Pierwszy uskutecznia się dzięki ciągłemu przyjmowaniu przez Kościół prawdziwych wartości ludzkich. Wartości te, związane $z$ różnorodnością etniczną, kulturową, narodową, nie tylko nie ponoszą przez to żadnego uszczerbku, lecz przeciwnie, zostają oczyszczone, umocnione i podniesione (por. KK 13). W ten sposób dokonuje się ewangelizacja ludzi i zbawienie świata, a Kościół, choć nieraz okazuje się jako mała trzódka, staje się prawdziwym zalążkiem jedności i zbawienia całego rodzaju ludzkiego (por. KK 9).

Wewnętrzny wymiar zwoływania Kościoła łączy Sobór z wewnętrznym jego doskonaleniem się, które realizuje się w czasie. Kościół bowiem, aczkolwiek święty w swej Głowie, nie od razu osiąga pełnię świętości w swych członkach. Tu, na ziemi, obejmuje on sobą nie tylko sprawiedliwych, lecz także ludzi słabych i grzesznych. Dąży on jednak nieustannie do doskonałości, wciąż się oczyszcza i upodobnia do swej Głowy (por. KK 8). Czasy ostateczne będą więc czasami doskonale zwołanego Ludu Bożego, czasami Kościoła. Obrazem i początkiem takiego właśnie Kościoła jest dziś Najświętsza Maryja Panna (por. KK 68).

\section{POWOEANIE KOSCIOŁA JAKO SAKRAMENTU ZJEDNOCZENIA BOGA Z LUDŹMI}

Zwołany dekretem Bożego postanowienia Kościół sam otrzymuje od Boga powołanie do spełnienia specjalnej misji. Sobór odszedł od podejścia do tajemnicy powołania rozważanego najpierw $w$ aspekcie indywidualnym, który to porządek narzucałaby lektura Ewangelii ${ }^{8}$, lecz przyjął w swej refleksji porządek ukazujący same początki powołania Ludu Bożego, opisane w pierwszych księgach Pisma świętego. Zanim przejdzie do opisywania powołań poszczególnych ludzi, ukaże on powołanie Kościoła jako całości. Kościół bowiem nie jest dla niego jedynie zbiorowiskiem wielu ludzi wyznających tę samą wiarę, lecz nadprzyrodzonym organizmem obecnym wśród ludzkości. Konstytucja Lumen Gentium widzi w Kościele „lud zjednoczony jednością Ojca i Syna, i Ducha Swwiętego", Mistyczne Ciało Chrystusa, Oblubienicę Chrystusową, a przede wszystkim, i to jest najbardziej oryginalne w stosunku do poprzednich wypowiedzi Kościoła Nauczającego, sakrament, czyli znak i narzędzie wewnętrznego zjednoczenia z Bogiem i jedności całego rodzaju ludzkiego 9. Kościół jako tajemnica, jako sakrament zjednoczenia ludzi z Bogiem, ma realizować specjalną misję od Boga.

8 Por. Ks. K. Romaniuk, tamże, 54.

9 O Kościele jako sakramencie mówi Sobór w wielu miejscach: KL 26, KK 1, KK 9, KK 48, DM 5. 
Najogólniej trzeba by powiedzieć, że misja ta jest kontynuowaniem misji Słowa Wcielonego. Kościół jednak nie jest Chrystusem kroczącym poprzez dzieje, lecz wspólnotą wiary, nadziei i miłości, ustanowioną przez Chrystusa i stanowiącą Jego wierne odbicie. „Dlatego też na zasadzie bliskiej analogii upodabnia się ona do tajemnicy Słowa Wcielonego. Jak bowiem przybrana natura ludzka służy Słowu Bożemu za żywe narzędzie zbawienia, nierozerwalnie z Nim zjednoczone, nie inaczej też społeczny organizm Kościoła służy ożywiającemu go Duchowi Chrystusowemu ku wzrastaniu ciała (por. Ef 4, 16)" (KK 8). Istotnym więc powołaniem Kościoła będzie odpowiednia „dyspozycyjność narzędzia” wobec swego Głównego Sprawcy. Z tym łączy się ściśle powołanie do odwzorowywania Chrystusa. Kościół musi kroczyć tą samą drogą, którą szedł Chrystus. Musi więc wraz z Nim przeżywać tajemnicę wyniszczenia zbawczego, musi praktykować ubóstwo, pokorę, wyrzeczenie, miłość bliźniego aż do służby, nieskalaność (por. KK 8).

Chrystocentryzm i teocentryzm Kościoła łączy się ściśle z powołaniem wobec ludzkości. Aby jednak Kościół mógł uświęcać i zbawiać, sam musi być wewnątrz spoisty i zjednoczony. „Podobało się bowiem Bogu uświęcać i zbawiać ludzi nie pojedynczo, z wykluczeniem wzajemnej między nimi więzi, lecz uczynić $\mathrm{z}$ nich lud, który by Go poznawał w prawdzie i święcie Mu służył" (KK 9). Charakterystycznym w nauce soborowej jest konsekwentne syntetyzowanie zadań i funkcji Kościoła. Tak też powołanie apostolskie jest ukazane jako pozostające w nierozdzielnym związku z powołaniem wobec siebie. To zewnętrzne powołanie Kościoła do świętości jest jednak pierwotne w stosunku do powołania wobec świata. Kościół powołany jest do świata jako światłość i jako sól ziemi, stąd też musi sam być święty (por. KK 9). Sobór wyakcentowuje w apostolstwie postawę dawania świadectwa przez wewnętrzną spoistość i doskonałość.

Powołanie Kościoła wobec całej rodziny ludzkiej, wobec świata, należy do ulubionych tematów ostatniego soboru. Nie tylko konstytucja o Kościele w świecie współczesnym poświęcona jest w całości tej prawdzie, ale także konstytucja dogmatyczna o Kościele. Charakterystycznym novum doktryny soborowej jest ukazanie Kościoła jako całkowicie otwartego wobec świata. Jest godnym zastanowienia, że wśród licznych figur i obrazów Kościoła, jakie wylicza Sobór w Lumen Gentium, nie znajdujemy ulubionej figury dawniejszych czasów, a mianowicie arki Noego. Jest on bardziej podobny do miasta świętego, do nowego Jeruzalem (por. KK 6), dostępnego dla wszystkich; owszem, do zaczynu zakwaszającego całe ciasto, do duszy społeczności ludzkiej, mającej doprowadzić tę społeczność do odnowy w Chrystusie i do przemiany w rodzinę Bożą (por. KDK 40). 
Kościół, który jest sakramentem zjednoczenia ludzi z Bogiem, ma się przyczyniać do zbawienia świata. Zbawienie to ma się jednak dokonać nie inaczej, jak tylko w rezultacie spotkania się powołania Kościoła i powołania świata. Konstytucja duszpasterska o Kościele nie będzie się wahała mówić o wzniosłym powołaniu ludzi (por. KDK 32), wyrastającym z faktu stworzenia ich przez Boga. Swiat bowiem w ujęciu tej konstytucji nie jest siedliskiem zła, lecz oznacza całą rodzinę ludzką ze wszystkim, wśród czego żyje (por. KDK 2); jest stworzony przez Boga i odkupiony przez Chrystusa; jest widownią historii rodzaju ludzkiego (por. KDK 2), jest głęboko związany z człowiekiem i dzięki niemu realizuje swój cel (por. KK 48) ${ }^{10}$. Tak pojętemu światu Kościół winien dawać nie tylko uczestnictwo w życiu Bożym, lecz także pomoc w jego ludzkiej wolności i godności; winien przyczyniać się, aby rodzina ludzka i jej historia stawały się bardziej ludzkie (KDK 40-43). Sam Kościół jest również wzbogacony przez świat. Żyje w nim i działa, partycypuje w swym wymiarze instytucjonalnym w przemijalności tego świata (por. KK48), a także jako rzeczywistość społeczna doznawał i doznaje jego pomocy (por. KDK 44). Rola Kościoła wobec świata ma więc zdaniem Soboru charakter służebny : w tym upodabnia się do swej Głowy, którą jest Chrystus.

\section{KOŚCIÓE MIEJSCEM URZECZYWISTNIANIA SIE POWOEAŃ POSZCZEGÓLNYCH LUDZI}

Rozważywszy powołanie Kościoła jako całości przechodzi Sobór do refleksji nad naturą powołania poszczególnych jego członków. Kościół jest bowiem Ludem Bożym złożonym z konkretnych osób, które cieszą się imiennym wezwaniem ze strony Boga. Sobór $z$ największą mocą akcentuje, że powołania te realizują się w strukturze Kościoła, dzięki przynależności do niego. „W każdym wprawdzie czasie i w każdym narodzie miły jest Bogu ten, ktokolwiek się Go lęka i postępuje sprawiedliwie (por. $\mathrm{Dz}$ 10, 35); podobało się jednak Bogu uświęcać i zbawiać ludzi nie pojedynczo, z wykluczeniem wszelkiej wzajemnej między nimi więzi, lecz uczynić z nich lud, który by Go poznawał w prawdzie i święcie Mu służył" (KK 9). Wiara więc poszczególnych członków Kościoła jest wiarą Kościoła, świętość poszczególnych jednostek jest świętością Kościoła. Sobór szczegółowo wykazuje, w jaki sposób przez poszczególne sakramenty chrześcijanin łączy się z Kościołem i otrzymuje za jego pośrednictwem łaskę świętości wewnętrznej (por. KK 11).

10 Od tego pojęcia ,świat" należy odróżnić znaczenie całkiem pejoratywne (por. J 17, 14-16). Sobór używa czasem pojęcia ,świat" w tym drugim sensie. Np.: DK 17, KK $42, \mathrm{KDK} 13$. 
Powołanie chrześcijańskie, biorące swój początek w sakramencie chrztu, jest ukazane przez Sobór jako zasadnicze i pierwotne w stosunku do powołań stanowych. Jest w tym konsekwencja i logika. Skoro poszczególne osoby uczestniczą w życiu Chrystusa i Jego kapłaństwie poprzez uczestnictwo w kapłaństwie Kościoła, to konsekwentnie powołanie ogólnochrześcijańskie musi być ukazane jako zasadnicze i źródłowe w stosunku do powołan partykularnych.

Ale i powołania partykularne ukazane są w dokumentach soborowych w kontekście tajemnicy Kościoła. W Mistycznym Ciele Chrystusa, podobnie jak w żywym organizmie, poszczególne części spełniają sobie właściwe zadanie, zawsze jednak dla dobra całości (por. KK 12). Sprawcą charyzmatów, zarówno najznamienitszych, jak i tych bardziej zwyczajnych a szerzej rozpowszechnionych, jest Duch Święty, lecz do Kościoła należy doświadczać wszystkiego i zachowywać to, co dobre (por. KK 12). Członkowie też Ludu Bożego „powołani są do wzajemnego udzielania sobie dóbr" (KK 13). Wszystkie zatem powołania charyzmatyczne indywidualne, są zdaniem nauki Soboru, zakorzenione $\mathrm{w}$ sercu tajemnicy Kościoła.

Wśród powołań stanowych na pierwszym miejscu stawia Sobór powołanie kapłańskie ministrów sakramentalnych. Oryginalnością jest w stosunku do dawniejszych koncepcji kapłaństwa usytuowanie go we wnętrzu niejako organizmu Kościoła. Często bowiem pod wpływem koncepcji Pseudo-Dionizego Areopagity stan kapłański przedstawiano jako pozostający w Kościele niejako od zewnątrz, a przynajmniej wyniesiony wysoko ponad chrześcijan, których określało się jako zwyczajnych chrześcijan. Wszelkie oczyszczenie, światło i doskonałość byłyby według tej koncepcji udzielane ludowi chrześcijańskiemu przez stan kapłański, zajmujący miejsce między Chrystusem a Kościołem ${ }^{11}$. Mimo słownych zastrzeżeń, że i kapłani również należą do Kościoła, w praktyce wychodziło na to, iż Kościół składa się z całkowicie różnych i oddalonych od siebie części: kierującej i kierowanej. II Sobór Watykański przedstawił w swych dokumentach inną wizję kapłaństwa hierarchicznego. Traktuje on o kapłaństwie ministrów sakramentalnych w następującej organicznej kolejności: najpierw przedstawia powołanie Chrystusa Kapłana, potem mówi o powołaniu kapłańskim Kościoła jako Ludu Bożego, by w trzeciej kolejności wskazać na powołanie sług konsekrowanych. Takie ujęcie nie umniejsza godności powołania kapłańskiego. Sobór z największą mocą wskazuje na istotną, a nie tylko różnicę stopnia między kapłaństwem powszechnym a hierarchicznym (por. KK 10). Ukazuje jednak łączność, jaka istnieje między nimi, ich wzajemne przyporządkowanie. „Jedno

11 Oeuvres complètes du Pseudo-Denys de l'Aréopagite, Paris 1943, Lettres VIII, 3, s. $349 \mathrm{n}$. 
i drugie bowiem we właściwy sobie sposób uczestniczy w jednym kapłaństwie Chrystusowym. Kapłan urzędowy, dzięki władzy świętej, jaką się cieszy, kształci lud kapłański i kieruje nim, sprawuje w zastępstwie Chrystusa (in persona Christi) ofiarę eucharystyczną i składa ją Bogu w imieniu całego ludu; wierni zaś, na mocy swego królewskiego kapłaństwa, współdziałają w ofiarowaniu Eucharystii; pełnią też to kapłaństwo przez przyjmowanie sakramentów, modlitwę i dziękczynienie, świadectwo świętego życia, zaparcie się siebie i czynną miłość" (KK 10).

Dokumenty ostatniego soboru z różnym efektem ukazują z jednej strony łączność, z drugiej strony odmienność zadań tych dwóch rodzajów uczestrictwa w kapłaństwie Chrystusa. Lepiej niż w dekrecie o życiu i posłudze kapłańskiej wyszło to w dekrecie o działalności misyjnej Kościoła. Tam wskazano na to, że od samego początku Pan Jezus ustanowił Dwunastu jako zasiew nowego Izraela i również zaczątek nowej hierarchii (por. DM 5). ,Z pism Nowego Testamentu wynika, że Apostoł i Wspólnota wiernych, których wzajemne związki poddane są Chrystusowi jako Głowie oraz natchnieniu Jego Ducha, wchodzą w skład niepozbywalnej, pierwotnej struktury Kościoła" - komentuje tę myśl dokument Synodu Biskupów z r. $1971^{12}$. Jedynie kapłani urzędowi dziedziczą po Apostołach świętą władzę powierzoną Kościołowi, cała wspólnota wiernych dziedziczy łaskę i godność kapłańską. Powołanie kapłanów znajduje się w wewnętrznej strukturze Kościoła, stanowi samoistny organizm pozostający w Kościele, a nie nad nim, czy też obok niego. Takie usytuowanie powołania kapłanów zostało wnikliwie przygotowane, zwłaszcza przez encykliki Piusa XII. Sobór uczynił to jeszcze wyraźniej ${ }^{13}$.

W tajemnicy Kościoła rozważa Sobór powołanie laikatu. Pod nazwą świeckich rozumie on „wszystkich wiernych chrześcijan nie będących członkami stanu kapłańskiego i stanu zakonnego, prawnie ustanowionego w Kościele, mianowicie wiernych chrześcijan, którzy jako wcieleni poprzez chrzest w Chrystusa, ustanowieni jako Lud Boży i uczynieni na swój sposób uczestnikami kapłańskiego, proroczego i królewskiego urzędu Chrystusowego, ze swej strony sprawują właściwe całemu ludowi chrześcijańskiemu posłannictwo w Kościele i w świecie" (KK 31). Konstytucja o Kościele łączy powołanie laikatu z powołaniem Kościoła jako Ludu Bożego. Aczkọlwiek bowiem do tego Ludu należą również kapłani i zakony, to przecież pewne charakterystyczne cechy tego Ludu mogą się urzeczywistnić w szczególny sposób w powołaniu świeckich (por. KK $30)$.

12 De sacerdotio ministeriali tłum. z ,Notificationes e Curia Metropolitana Cracoviensi", $1-3$ (1972) 7 .

13 Chodzi głównie o encyklikę „Mediator Dei”, w której Pius XII rozważa kapłaństwo hierarchiczne w kontekście kapłaństwa Kościoła zaznaczając przy tym, że nie pochodzi ono z emanacji kapłaństwa wiernych. Por. AAS 39 (1947) 521—595. 
Powołanie laikatu osiąga mianowicie swój szczególny związek z posłannictwem Kościoła przez swój związek ze światem. Jest ono związane z oddziaływaniem Kościoła na świat przez samą obecność w nim. Ludzie świeccy, dzięki temu, że żyją w świecie, wśród spraw i obowiązków świata, że ich egzystencja życiowa utkana jest ze zwyczajnych warunków życia rodzinnego, społecznego, ekonomicznego i politycznego, mogą uświęcać ten świat przenikając go duchem ewangelicznym niejako od wewnątrz, na kształt ewangelicznego zaczynu (por. KK 30).

Nie można jednak zbyt ostro rysować granic między powołaniem kapłanów, zakonów i ludzi świeckich. I Sobór tego nie czyni. Ukazując wciąż jako zasadnicze i główne powołanie Kościoła jako Bożego Ludu, sprowadza do wspólnego mianownika wszystkie powołania stanowe. Tak też, jak kapłani i zakony winni być obecni w świecie i uświęcać go przez samą już w nim obecność, tak również i laicy winni oddawać się apostolstwu zewnętrznemu. Owszem, w pewnych przypadkach ich apostolstwo jest nie do zastąpienia przez duchownych i osoby zakonne. Tylko oni mogą uobecnić Kościół w warunkach, miejscach i okolicznościach szczególnie trudnych, do których nie mają dostępu kapłani (por. KK 33). W ogóle, powołaniem laikatu jest współpracować z Hierarchią w rozszerzaniu Królestwa Bożego na ziemi ${ }^{14}$. Sobór poświęci temu zagadnieniu obszerny dokument o apostolstwie świeckich.

O powołaniu stanu zakonnego Sobór uczy po wskazaniu na powszechne powołanie do świętości wszystkich chrześcijan, po określeniu, na czym polega specyfika powołania kapłanów i świeckich, a przed określeniem Kościoła jako pielgrzymującego i mającego organiczny związek z Kościołem w niebie. Nie jest to dziełem przypadku. Powołanie stanu zakonnego w strukturze Kościoła da się zrozumieć wtedy, gdy się je rozważa w takim właśnie kontekście.

Powołanie zakonne nie specyfikuje się wcale, z racji jakiejś pośredniości między stanem kapłańskim a stanem świeckich. „Bóg powołuje niektórych chrześcijan, aby w życiu Kościoła korzystali ze szczególnego daru i byli, każdy na swój sposób, pomocni w zbawczym Jego posłannictwie" (KK 43). Niewątpliwie, mają się oni przyczyniać do dobra całego Kościoła przez oddanie się mu na wzór stanu kapłańskiego, a więc przez poświęcenie się szerzeniu Królestwa Bożego na ziemi w apostolstwie. Mają oni jednak specyficzną, sobie właściwą funkcję w Kościele. Różnymi pojęciami operuje Sobór, aby tę funkcję określić. Można je ostatecznie

14 Apostolskie powołanie świeckich zostało przez Sobór zaakcentowane, jak nigdy dotychczas. Wyrazem tego jest zdanie: „Kościól bez wysiłku świeckich przestałby prawie istnieć i działać" (DA 1). Trzeba jednak pamiętać o wkładzie, jaki mają w tej dziedzinie papieże: Pius XI i Pius XII. Por. enc. Piusa XI „Quamvis nostra”, AAS 28 (1936) 160 n.; enc. „Ubi arcano”, AAS 14 (1922) 659; enc. Piusa XII „Summi Pontificatus”, AAS 31 (1939) 442 n. i także Pius XII w licznych swych przemówieniach do różnych grup ludzi świeckich. 
sprowadzić do jednej, a mianowicie: oznaczanie eschatologicznego charakteru Kościoła. Kościół bowiem w istocie swojej jest Ludem Bożym, pielgrzymującym przez ten świat, do świata innego; antycypuje on jednak te dobra już teraz, uobecnia je już tu na ziemi. Stan zakonny ma w szczególniejszy sposób wyrażać obecność tych dóbr w Kościele. Czyni to przez przyjęcie daru rad ewangelicznych. Tym samym ,,pociąga skutecznie wszystkich członków Kościoła do ochoczego wypełniania powinności powołania chrześcijańskiego” (KK 44). Stan zakonny „daje świadectwo nowemu i wiekuistemu życiu, zyskanemu dzięki odkupieniu przéz Chrystusa”, „zapowiada przyszłe zmartwychwstanie i chwałę Królestwa Niebieskiego" (KK 44).

To szczególniejsze związanie powołania zakonnego z tajemnicą Kościoła w jego eschatologicznym rysie nie świadczy o wyobcowaniu go od ludzi i społeczności ziemskiej. Wielka troska Soboru o adaptację form życia zakonnego do warunków współczesnych dowodzi tego najwymowniej. Sobór pragnie jednak przypomnieć, że stan zakonny ma wciąż głosić prawdę, iż Kościół jest na świecie, ale nie jest z tego świata. Powołanie zakonne tkwi, podobnie jak powołanie laikatu, w samej naturze Kościoła. Powołaniem laikatu jest „udocześnianie” Kościoła, powołaniem zakcnów jego „oddocześnianie”; powołaniem pierwszych „wcielanie” go w rzeczywistość świata; powołaniem drugich „wyprowadzanie” z tego świata. W ten sposób Kościół realizuje swoje posłannictwo dane mu przez Boskiego Założyciela.

\section{KOŚCIÓE CELEM DLA REALIZUJĄCYCH SIE POWOEAÑ}

Dokumenty soborowe ukazują Kościół nie tylko jako miejsce urzeczywistnienia się powołań, ale również jako punkt odniesienia w ich urzeczywistnianiu się. Powołania są dla Kościoła, dla jego dobra i pożytku. Kościół jest ich przyczyną celową. Nie pozostaje to w sprzeczności z teocentryzmem i chrystocentryzmem Soboru. Wypowiedzi jego wciąż uwypuklają trynitarny charakter życia chrześcijańskiego, to że dzieje się ono przez Chrystusa w Duchu Swiętym dla Ojca (por. KK 4). Nieustannie też akcentują, że Chrystus jest celem wszelkich powołań urzeczywistniających się w Kościele. Usiłują jednalkże łączyć chrystocentryzm z eklezjalnym aspektem powołania. Ukazują więc Kościół nie tylko jako sakrament zjednoczenia Boga z ludźmi i Lud Boży zebrany w Chrystusie i wędrujący do Boga, ale też jako wciąż dopełniające się Mistyczne Ciało Chrystusa (KK 7) i wciąż udoskonalającą swą miłość Oblubienicę Chrystusa (KK 6). Tak więc „na obliczu Kościoła jaśnieje blask Chrystusa” (KK 1), a Chrystus siedząc po prawicy Ojca działa ustawicznie w świecie”, „,aby prowadzić ludzi do Kościoła i przezeń mocniej ich z sobą złączyć” (KK 48). 
Wszyscy więc jesteśmy powołani do Kościoła w Chrystusie, do przysparzania jego świętości, „na większą chwałę jednej i niepodzielnej Trójcy” (KK 47).

Ubogacanie Kościoła, zasadniczy obowiązek wszystkich ochrzczonych, łączy się w myśli soborowej z uświęcającym działaniem Ducha Świętego. To on „utrzymuje Kościół w ciągłej młodości, ustawicznie go odnawia i do doskonałego z Oblubieńcem zjednoczenia prowadzi. Albowiem Duch i Oblubienica mówią do Pana Jezusa: Przyjdź! (por. Ap 22, 17)" (KK 4). Duch Swięty tėz udziela swoich darów stosownie do potrzeb posługiwania ku pożytkowi Kościoła ( $\mathrm{KK}$ 7). Przeróżne to są dary; charyzmaty „,najznamienitsze” i charyzmaty ,bardziej zwyczajne a szerzej rozpowszechnione", dary udzielane w porządku sakramentalnym i pozasakramentalnym, dobra poszczególnych ras i narodów, dary związane z życiem poszczególnych stanów - wszystkie są dane dla Kościoła. Wynika stąd obowiązek dzielenia się tymi darami, aby tym lepiej zrealizowało się dobro Kościoła. „Członkowie Ludu Bożego - głosi konstytucja Lumen Gentium - powołani są do wzajemnego udzielania sobie dóbr” (KK 13). Dzięki tej wzajemnej wymianie darów objawia się w całej pełni świętość Kościoła.

W dokumentach soborowych wiele miejsca poświęcono zadaniom kościelno-twórczym poszczególnych powołań stanowych. Ukazywane są one dwojako: jako te, które przyczyniają się wprost do budowy Mistycznego Ciała Chrystusa, do jego wzrostu i mocy lub też te, które udoskonalają i upiększają Kościół od wewnątrz.

W pierwszej grupie znajduje się nade wszystko powołanie kapłańskie. Nie trudno zauważyć, że Sobór przedstawił kapłaństwo w aspekcie eklezjalnym. Pobieżna lektura jego dokumentów moglaby nawet nasunąć myśl, że została przy tym zagubiona opcja chrystocentryczna. Niektóre partie dekretu o posłudze i życiu kapłanów mogłyby wskazywać na to, że kapłan w wizji Soboru nie jest już mężem Eucharystii w takim stopniu, jak to ukazywała teologia potrydencka. Z pewnością wyakcentował on funkcję głoszenia słowa Bożego o wiele bardziej, niż to dawniej czyniono ${ }^{15}$. W istocie jednak Sobór nie deprecjonuje funkcji eucharystycznej kaplaństwa i nie stawia jej na drugim miejscu, po funkcji profetycznej. Swiadczą o tym słowa, w których określa się kapłaństwo przez odniesienie do Eucharystii (por. KK 28). Faktem natomiast jest, że dokumenty soborowe chętnie definiują kapłaństwo hierarchiczne przez jego związek

15 W Presbyterorum Ordinis omawiając obowiązki prezbiterów Sobór na pierwszym miejscu wymienia posługę słowa, potem szafarstwo sakramentów i Eucharystii wreszcie kierowanie Ludem Bożym. (por. DK 4, 5,6). Wychodzi bowiem z założenia, że przyjęcie słowa Bożego jest podstawowym aktem wiary, który jednak osiąga swój szczyt w życiu eucharystycznym. Teologia potrydencka walcząc z reformacją nie dość mocno akcentowała funkcję kapłana wobec słowa Bożego. 
z Kościołem: „Prezbiterzy... przez święcenia i misję otrzymywaną od biskupów zostają wyniesieni do służenia Chrystusowi Nauczycielowi, Kapłanowi i Królowi, uczestnicząc w Jego posłudze, dzięki której Kościół tutaj na ziemi nieustannie staje się Ludem Bożym, Ciałem Chrystusa i Świątynią Ducha Świętego” (DK 1). „Urząd prezbiterów, jako związany ze stanem biskupim, uczestniczy we władzy, mocą której sam Chrystus Ciało swoje buduje, uświęca i nim rządzi. Dlatego też kapłaństwo prezbiterów zakłada wprawdzie sakramenty chrześcijańskiego wtajemniczenià, zostaje jednak udzielone przez ten specjalny sakrament, mocą którego prezbiterzy, dzięki namaszczeniu Ducha Swiętego, zostają naznaczeni szczególnym znamieniem i tak upodabniają się do Chrystusa Kapłana, aby mogli działać w osobie Chrystusa Głowy". (DK 2). Jest więc kapłan urzędowym sługą Chrystusa Głowy na służbie Kościoła jako Mistycznego Ciała. Można by powiedzieć, że Sobór zdaje się uzupełniać tradycyjne wyrażenie, i tak ulubione przez Piusa XII: kapłan to „drugi Chrystus” 16, dodatkiem: „w służbie Kościołowi” czy „,jako Głowa Kościoła”. Sobór rezerwuje dla funkcji kapłanów niektóre formy budowania Mistycznego Ciała Chrystusa. Z pewnością tylko oni są sprawcami Eucharystii, dzięki której rośnie Kościół, oni kształcą lud kapłański i wychowują go (por. KK 10). Inne jednak stany również przyczyniają się do rozwoju Kościoła.

Sobór wskazuje na stan zakonny (por. KK 44) i na laikat jako na powołania urzeczywistniające się dla dobra Kościoła. Laicy przyczyniają się do wzrostu Kościoła i do jego świętości, czynią go bowiem obecnym i aktywnym w takich okolicznościach i w takich miejscach, gdzie jedynie przy ich pomocy może on spełnić swoją misję (por. KK 33). Współpracują z Hierarchią przez dialog w sprawie apostolskiej Kościoła (KK 37), w znacznym stopniu przyczyniają się do jego rozwjou przez dzieło apostolskie.

$\mathrm{Na}$ szczególną uwagę zasługuje nauka Soboru na temat powołania małżonków w rodzinie i określenie go jako powołanie ,w domowym niejako Kościele” (KK 11). „Tam małżonkowie znajdują swoje powołanie, polegające na tym, że mają oni być dla siebie nawzajem i dla dzieci swoich świadkami wiary i miłości Chrystusa. Rodzina chrześcijańska pełnym głosem oznajmia zarówno obecne cnoty Królestwa Bożego, jak i nadzieję błogosławionego żywota. W ten sposób swoim przykładem i świadectwem przekonuje świat o jego grzechu i oświeca tych, co szukają prawdy" (KK 35).

Powołania chrześcijańskie odnoszą się do Kościoła również i w ten sposób, że wyrażają jego mistyczny związek z Chrystusem. Dotyczy to wszystkich stanów, szczególnie jednak powołania zakonnego.

16 Por. adhortację Piusa XII „Menti Nostrae”, AAS 42 (1950) 659 n. 
Sobór łączy istotę powołania zakonnego z oblubieńczym związkiem Chrystusa z Kościołem zarówno w konstytucji dogmatycznej o Kościele, jak i w dekrecie o przystosowanej odnowie życia zakonnego. Dzieki wspólnotom zakonnym, różnorakim w swoich celach i konkretnych założeniach, „Kościół jest nie tylko przysposobiony do wszelkiego dobrego dzieła i gotowy do wykonywania posługi celem budowania Ciała Chrystusowego (Ef 4,12), lecz także okazuje się ozdobiony różnymi darami, jak oblubienica strojna dla męża swego (por. Ap 21, 2), i przezeń daje się poznać wieloraka mądrość Boża (por. Ef 3, 10). (DZ 1). Oddając się Chrystusowi osoby zakonne sprawiają, że życie Kościoła staje się bujniejsze a jego apostolskie dzieło daje lepsze owoce (por. DZ 1). Ten oblubieńczy związek Kościoła z Chrystusem wyrażają zakony przez całożyciowe oddanie, lecz przede wszystkim przez cnotę doskonałej czystości. Wtedy to najlepiej ,przypominają wyznawcom Chrystusa owe przedziwne zaślubiny ustanowione przez Boga, a mające objawić się w przyszłym świecie, mocą których Kościół ma Chrystusa jako jedynego Oblubieńca" (por. DZ 12).

Również w tajemnicy związku Chrystusa z Kościołem widzi Sobór celowość powołania małżeńskiego: „Małżonkowie chrześcijańscy na mocy sakramentu Małżeństwa wyrażają tajemnicę jedności i płodnej miłości pomiędzy Chrystusem i Kościołem i w niej uczestniczą" (KK 11); ,stają się świadkami oraz współpracownikami płodności Matiki-Kościoła" (KK 41); oznaczają miłość, jaką Chrystus umiłował Kościół i wydał za niego samego siebie (por. KK 41). Dziewictwo osób zakonnych ukazuje bardziej zaślubiny Chrystusa $\mathrm{z}$ Kościołem, które będą miały miejsce $\mathrm{w}$ życiu przyszłym, małżeństwo natomiast ukazuje piękno tego związku Chrystusa z Kościołem w życiu ziemskim Chrystusa i Kościoła. Obydwa stany przyczyniają się w sobie właściwy sposób do duchowej płodności Kościoła.

Mówiąc o związku powołań: kapłańskiego, zakonnego i małżeńskiego z tajemnicą wzrostu i duchowego piękna Kościoła w nauce II Soboru Watykańskiego trudno nie zwrócić uwagi na przygotowanie terenu $\mathrm{w}$ tej materii przez encykliki Piusa XI, a zwłaszcza Piusa XII ${ }^{17}$. Zasługą Soboru było wkomponowanie tych prawd w całą konstrukcję nauki o Kościele i o powołaniu.

Przedstawienie poszczególnych powołań jako realizujących się dla Kościoła, dla jego dobra, pożytku, wzrostu, chwały i piękna należy do ulubionych myśli Soboru. W każdym bądź razie odciął się on od przedstawiania pewnych powołań, jako urzeczywistniających jedynie cel teolo-

17 Por. wypowiedzi Piusa XI: enc. „Casti connubii”, AAS 22 (1930) 544 n. i enc. „Ad sacerdoti nostri fastigium", AAS 20 (1936) 12-19; wypowiedzi Piusa XII: adh. „Menti Nostrae", AAS 42 (1950) 675 n.; list apost. „Sponsa Christi”, AAS 43 (1951) 20 ; enc. ,Sacra virginitas”, AAS 46 (1954) 172-176. 
galny czy też własne doskonalenie się w oderwaniu od wewnętrznej struktury Kościoła. Dla Soboru wszystkie stany powołane są dla Boga, który nas prowadzi do siebie poprzez Kościół, a więc także i dla Kościoła.

\section{KOŚCIÓ£ JAKO POWOEUJĄCY}

Rozważając eklezjalny aspekt powołania w nauce II Soboru Watykańskiego nie można nie zwrócić uwagi jeszcze na jedną jego formę, a mianowicie, że Kościół bierze udział w akcie powołania, że jest powołującym do pewnych zadań związanych $\mathrm{z}$ realizacją boskiego planu zbawienia.

Konstytucja o Kościele przedstawia zadania Kościoła na ziemi jako kontynuowanie misji Słowa Wcielonego: „Obiecane odnowienie, którego oczekujemy, już się rozpoczęło w Chrystusie, postępując dalej w zesłaniu Ducha Świętego i przez Niego trwa w Kościele" (KK 48). Kościół nie jest jednak dla Soboru drugim Chrystusem, kroczącym poprzez dzieje do wypełnienia czasów, lecz sakramentem Chrystusa i Jego związku z ludzkością; i dlatego jest on powołującym w innym sensie niż Chrystus. Powołanie jest rzeczywiście jedno, a mianowicie boskie (KK 22). Jest ono ściśle związane z dziełem stworzenia, odkupienia i uświęcenia, stąd jego autorem jest Bóg Ojciec, Syn i Duch Swięty. Kościół może być jedynie uczestnikiem $\mathrm{w}$ tajemnicy powoływania i jego interpretatorem. W tym też znaczeniu można o nim mówić jako o powołującym.

Kościół partycypuje w tajemnicy powoływania człowieka do osiągania przez niego pełni swojego człowieczeństwa. Może on człowiekowi pomóc rozpoznać własną tożsamość. Może mu - mówi Sobór — odpowiedzieć na pytanie, wyjaśnić mu jego słabości ukazując ich źródło, umożliwić należyte uznanie własnej godności i rozpoznanie swego powołania (por. KDK 12). Ta moc Kościoła płynie oczywiście z jego związku z Chrystusem. „Tajemnica człowieka - uczy Sobór - wyjaśnia się naprawdę dopiero w tajemnicy Słowa Wcielonego. Albowiem Adam, pierwszy człowiek, był figurą przyszłego, mianowicie Chrystusa Pana. Chrystus, nowy Adam, juz w samym objawieniu tajemnicy Ojca i Jego miłości, objawia w pełni człowieka samemu człowiekowi i okazuje mu najwyższe jego powołanie" (KDK 22).

To ułatwianie rozpoznawania powołania ludzkiego przez Kościół odnosi się także do wymiaru społecznego. Ukazuje on ludzkości wartość jej zaangażowania się w rozwój doczesny tego świata. Wyprowadza ją z beznadziejności, dając jej nadzieję i ukazując jej perspektywę życia wiecznego. „Bóg bowiem powołał i powołuje człowieka, aby przylgnął do Niego całą swą naturą w wiecznym uczestnictwie nieskazitelnego życia Bożego" (KDK 18). Kościół uczy przy tym, że nadzieja eschatologiczna nie 
pomniejsza doniosłości zadań ziemskich (KDK 20). Misję swą wypełnia Kościół nie tylko przez swą doktrynę, lecz także przez swe życie: ,zadaniem bowiem Kościoła jest uobecniać i czynić niejako widzialnym Boga Ojca i Jego Syna Wcielonego przez nieustanne odnawianie się i oczyszczanie pod kierunkiem Ducha Świętego" (KDK 21). Środkiem do tego jest miłość brâterska, jaka realizuje się w Kościele. Istotnym zadaniem Kościoła będzie zawsze nie tylko być znakiem zbawczym zjednoczenia ludzkości z Bogiem, lecz także zjednoczenia ludzi w jeaną rodzinę (por. KK 1).

Sobór w szczególniejszy sposób łączy realizację powołania ogólnochrześcijańskiego z pośredniczącą rolą Kościoła wskazując na związek życia chrześcijańskiego z porządkiem sakramentalnym, którego depozytariuszem jest Kościół. Wierni przez chrzest wcieleni do Kościoła za jego pośrednictwem otrzymują wiarę i powołanie do jej wyznawania przed Iudźmi. Przez sakrament Bierzmowania jeszcze ściślej wiążą się z Kościołem i diałego jeszcze mocniej są zobowiązani do szerzenia wiary słowem i uczynkiem oraz do bronienia jej. Kościół przyczynia się do pojednania grzeszników z Bogiem, a chorych przez święte namaszczenie poleca cierpiącemu i uwielbionemu Panu (por. KK 11). Pod przewodem też Kościoła cały lud chrześcijański realizuje funkcję proroczą, kapłańską i królewską, dzieje się to zaś tym sprawniej, że przełożeni w Kościele doświadczają wszystkiego i zachowują to, co dobre (por. KK 12).

O funkcji powołującej ze strony Kościoła Sobór mówi wprost w odniesieniu do kapłaństwa. „Opatrzność Boża — głosi dekret o formacji kapłańskiej - prawowitym szafarzom Kościoła zleca, aby odpowiednich kandydatów, którzy zdążają w szczerej intencji i całkienı dobrowolnie do tak wielkiego zadania, po uznaniu ich zdatności, powoływali i pieczęcią Ducha Swiętego konsekrowali do kultu Bożego i służby kościelnej" (DFK 2). W tej materii Sobór idzie za głosami wielu papieży naszego stulecia, którzy w swych encyklikach o kaplaństwie z największą mocą podkreślali, że ostatecznym głosem powoỉującym do kapłaństwa jest akt święceń kapłańskich, udzielanych przez prawowitego biskupa Kościoła ${ }^{18}$.

18 Sw. Pius X określił swe stanowisko na temat powoływania do kapłaństwa przez odpowiedni autorytet Kościoła nie tylko w antymodernistycznych encyklikach, ale również w liście Sekretariatu Stanu z 1912 r., napisanym z okazji wydania dzieła pt. Powołanie kapłańskie przez Józefa Lahitton'a. W liście tym podkreślono, że biskup jest tym, który w imieniu Kościoła powołuje do kapłańskiej służby. Odrzucił on tym samym opinie, które sprowadzały powołanie jedynie do wewnętrznego pociagu, czy té̇ do enigmatycznego odczuwania zaproszenia Ducha Swiętego (por. AAS 4 (1912) 485). Ta nauka Soboru Trydenckiego została z kolei przypomniana przez Benedykta XV w enc. „Maxumum illud”. Papież nakazuje powolywać do kapłaństwa jedynie tych, którzy odznaczają się odpowiednimi przymiotami intelektualnymi i moralnymi i posiadaja w duszy semina Apostolorum. (por. AAS 11 (1919) 452). Takie ujęcie znalazło swój wyraz w Kodeksie Prawa Kanonicznego (k. 1355), a następnie w wypowiedziach Piusa XI (por. enc. "Mens nostra”, AAS 21 (1929) 701). 
Ten urzędowy akt powołania do kapłaństwa jest jednak dla Soboru ostateczną fazą tajemaicy powolania. Kościół uczestniczy w akcie powołania do kapłaństwa juz wcześniej, a mianowicie weryfikując prawdzi.wość tego powołania. Powołanie kapłańskie jest bowiem darem samego Chrystusa, a do Kościoła, pewnych jego przedstawicieli, należy zbadanie znaków powołania i selekcja kandydatów do kapłaństwa (por. DFK 6). Papieże ostatnich czasów będą się wprost prześcigiwać $\mathrm{w}$ przypominaniu biskupom i przełożonym seminaryjnym tego obowiązku ${ }^{19}$. Dekret o formacji kapłańskiej na nowo zestawia listę znaków powołania do kapłaństwa (por. DFK 6).

Jeszcze więcej miejsca poświęca Sobór obowiązkowi budzenia i pielęgnowania powołań kapłańskich. Także i w tej dziedzinie idzie on za bardzo bogatą tradycją Nauczającego Kościoła ostatnich dziesiątków lat ${ }^{20}$. To, co stanowi o nowym akcencie jego nauki w tej dziedzinie, to podkreślenie, że cały Kościói jest odpowiedzialny za dzieło budzenia powołań. „Obowiązek budzenia powołań ciąży na całej społeczności chrześcijańskiej, która winna spełniać go przede wszystkim przez życie w pełni chrześcijańskie" - głosi na początku rozdziału o powołaniu do kapłaństwa dekret Optatam totius (DFK 2). Cały Kościól bierze jakiś udział w samym akcie powołania.

Powołującą rolę Kościoła dostrzega również Sobór w odniesieniu do powołania zakonnego. Widzi ją najpierw w ogólnym kierownictwie życiem zakonnym. Kościół więc tłumaczy rady ewangeliczne pod przewodnictwem Ducha Swiętego, kieruje ich praktykowaniem i ustanawia trwałe formy życia oparte na tych radach (por. KK 43). Hierarchia kościelna więc konsekwentnie przyjmuje reguły przedstawione przez zakonodawców, oficjalnie je zatwierdza i czuwa nad tym, by wzrastały i rozwijały się w duchu założycieli (por. KK 45).

Sobór, podobnie jak to czynił w odniesieniu do powołania kapłańskiego, akcentuje akt Kościoła angażujący poszczególnych chrześcijan do życia zakonnego. Niewątpliwie inny ma on charakter; profesja zakonna nie jest przecież sakramentem, cieszy się on jednak szczególną powagą: „Ko-

19 Por, enc. Leona XIII ,Quod multum”, Acta Leonis 6, s. 158; enc. Piusa XI „Ad catholici nostri fastigium”, AAS 28 (1936) 38-45; adh. ,Menti Nostrae”, AAS 42 (1950) $684-686$.

20 W historii dokumentów Kościoła Nauczajacego można dostrzec proces coraz to pełniejszego uświadamiania sobie przez Kościół odpowiedzialności za pielęgnowanie kapłańskich i zakonnych powołań. Kodeks Prawa Kanonicznego porucza tę troskę biskupom i proboszczom (k. 1353). Pius XI mówi o roli Akcji Katolickiej i wychowania rodzinnego w tym względzie. Uwypukla miejsce modlitwy i dzieł budzenia powołań (por. enc. „Ad catholici nostri fastigium”, AAS 28 (1936) 46). Pius XII poszerza jeszcze krąg odpowiedzialnych za akcję budzenia powołań (por. adh. „Menti Nostrae", AAS 42 (1950) 648). Dekret soborowy Optatam totius mówi o odpowiedzialności biskupów i kapłanów, chrześcijańskich rodzin, wychowawców, stowarzyszeń i całej wspólnoty Kościoła. Zaleca takie środki jak: ciągła modlitwa, pokuta i uświadamianie wiernych o powszechnej odpowiedzialności za powołania. 
ściół również na mocy władzy udzielonej mu przez Boga przyjmuje śluby od tych, którzy je składają, publiczną swą modlitwą wyprasza im pomoce i laskę u Boga, poleca ich Bogu i udziela im duchowego błogosławieństwa łącząc ich ofiarę z ofiarą eucharystyczną" (KK 45). Wpierw jednak. Kościoł troszczy się o rozwój powołań zakonnych (por. DZ 24).

I w powoływaniu świeckich do spełniania właściwych im funkcji widzi ostatni Sobór szczególniejszą rolę Kościoła. Zwłaszcza w sprawowaniu funksji apostoiskiej laikat musi się liczyć z myślą całcgo Kościoła, wyrażającą się w nauczaniu Hierarchii (por. DA 6). Nie znaczy to wcale, że powolanie świeckich do apostolatu jest jedynie dziełem Hierarchii. Dekret - apostolstwie świeckich przypomni, że świeccy ,wszczepieni przez chrzest w Cialo Mistyczne Chrystusa, utwierdzeni mocą Ducha Świętego przez bierzmowanie, są przeznaczeni przez Pana do apostolstwa" (DA 3). Hierarchia jest jednak przewodnikiem w przeprowadzaniu tego apostolstwa. Ona zaleca i pochwala niektóre jego formy, inspiruje je, czuwa nad jego przebiegiem, porządkuje je i koordynuje (por. DA r. V). Wyraźnym aktem powoływania swieckich przez Hierarchię do apostolstwa jest udzielanie przez nią niektórym osobom świeckim mandatu (por. DA 24).

Różne wyrazy przyjmuje troska Kościoła o realizację poszczególnych powołań i Sobór wnikliwie ją ukazuje. Wyrasta to zawsze z świadomości, że Kościół uczestniczy w tajemnicy Chrystusa, który powoływał do wykonywania zbawczych za dań w śród l u d zi.

Podsumowując refleksje na temat eklezjalnego aspektu powołania w wypowiedziach II Soboru Watykańskiego trzeba by z mocą wskazać na ścisły związek prawdy o powołaniu z tajemnicą Kościola, jaki tam został ukazany. Właśnie w świetle prawdy o Kościele objawiło się całe bogactwo życia chrześcijańskiego, rozważanego pod kątem powołania. I na odwrót, prawda o Kościele, której Sobór poświęcił najwięcej swoich przemyśleń, zyskała bardzo wiele, dzięki nawiązaniu do biblijnej idei powołania wszystkich w Jezusie Chrystusie. Jeśli dawniej idea ta nie dość może była wykorzystana przez refleksję teologiczną, a nawet przez Urząd Nauczycielski Kościoła, to dlatego, że eklezjologia skoncentrowana na wysiłku apologetycznym nie dość wnikała w samą tajemnicę Kościoła. Nie będzie więc przesadą stwierdzić, że Bóg w planach swoich zostawił Kościołowi naszych czasów medytację nad tą prawdą, aby jak ewangeliczny gospodarz mógł je wyciągać ze swego skarbca i cieszyć się nimi. 


\section{L'ASPECT ECCLÉSIAL DE LA VOCATION À LA LUMIERE DU VATICAN II}

\section{R E S U M E}

La vocation chrétienne appartient aux idées principales du Concile Vatican II. Les principaux documents du Concile, surtout Lumen Gentium et Gaudium et Spes, la traitent copieusement, et toujours dans le contexte du mystère de l'Eglise. Ce fait donne à l'auteur de l'article le point de départ dans ses analyses des textes du Concile, intitulées: „L'aspect ecclésial de l'idée de vocation dans les documents du Concile Vatican II". Il traite son sujet dans cinq parties.

La première constate que le Concile décrit l'Eglise comme une convocation des hommes au salut. Cette convocation s'affectua une fois dans l'histoire et, en même temps, elle s'effectue dans l'histoire du salut. L'Eglise est toujours convoquée par Dieu; elle s'incarne dans toutes les nations, civilisations et cultures, et surtout, elle se sanctifie et s'approche à son Divin Epoux. Ce n'est qu'à la fin du monde qu'elle sera parfaitement convoquée.

Mais l'Eglise, elle-même appelée de Dieu, reçoit de part de Dieu une vocation. L'article prend en considération ce sujet dans sa deuxième partie. L'Eglise continue la mission salvatrice du Christ, et pour cette raison, elle doit être disponible par rapport à Lui et reproduire Sa sainteté. La dimension théologale de la vocation de l'Eglise est organiquement liée à celle envers le monde. L'Eglise, sacrement de l'union des hommes avec Dieu, est appelée de sauver le monde. Le Concile n'approche pas l'Eglise à la figure de l'arche de Noé en s'attachant plutôt à celle de la ville, située sur la montagne et ouverte à tous.

Après avoir montrée la vocation de l'Église comme sacrement et Corps Mystique du Christ, le Concile considère la vocation de ses membres. Cette pensée est l'objet d'analyse de la troisième partie de l'article. La vocation des baptisés prend la priorité par rapport aux vocation des états particuliers. La vocation du prêtre est située à l'intérieur de l'Eglise par contre à la conception de la théologie posttridentine, qui influencée par les idées dionysiennes, le plaçait un peu au-dessus de l'Eglise. Au centre du mystère de l'Eglise, le Concile place aussi la vocation des laics. Ce sont eux en effet qui doivent faire présente l'Eglise au sein du monde en lui donnant une valeur théologale. La vocation des réligieux exprime le mieux l'attude eschatologique de l'Eglise, et pour cela elle reste au coeur de sa mission.

Le quatrième point de l'article présente l'Eglise comme cause finale des vocations particulières. La vocation sacerdotale, religieuse et laicale, s'effectue pour un bien de l'Eglise. Dans les documents du Concile, on peut indiquer deux options de cet aspect ecclésial de la vocation: l'une nous montre que les vocations (surtout celle des prêtres, des foyers) se réalisent pour donner à l'Eglise de l'accroissement, pour construire le Corps Mystique du Christ; l'autre fait voir que les vocations (surtout celle des religieux et des religieuses aussi bien que celle du mariage chrétien) s'effectuent pour exprimer les liens d'amour qui existent entre le Christ et l'Eglise.

La cinquième partie démontre que l'Eglise est aussi un sujet de la vocation. Elle participe dans l'acte de vocation, qui a toujours Dieu comme l'Auteur principal. L'Eglise aide l'homme de trouver son identité humaine, sa dignité personnelle; appelle au sacerdoce par l'acte des ordinations; accepte les voeux de religion; donne le mandat aux laïs d'exercer un apostolat. 